\title{
A Study of Molar Pregnancy at Tertiary Centre of India
}

\author{
Dineshkumar $^{1}$, Y Ajitkumar Singh ${ }^{2}$, L Somenkumar Singh ${ }^{3}$, \\ L Ranjit Singh ${ }^{4}$, Paya Liyak ${ }^{5}$, Alvencia Vaz ${ }^{6}$ \\ (Regional institute of medical sciences RIMS Imphal,Manipur) \\ Post graduate ${ }^{1,5,6}$ \\ Assistant professor ${ }^{2}$ \\ Senior resident ${ }^{3}$ \\ Professor $^{4}$
}

\begin{abstract}
Molar pregnancy is form of the disease, that is benign in nature. There is a wide variation in incidence reported worldwide which has been contributed by genetic, environmental,demographic and hostrelated factors. In our study total number of deliveries from $1^{\text {st }}$ October to 30june were 8104 .There were 37 molar pregnancies. The incidence was 4.5656 per 1000 deliveries. We found most of the result from remote area ,low socio economic status and low education level women. In our study of molar pregnancy parity one and above were more than $70 \%$ and there were thirty percent of nulliparous pregnancy.
\end{abstract}

Keywords.Molar,hydatiform mole,pregnancy, beta HCG.

\section{Introduction}

Molar pregnancy (hydatidiform mole) is known as the pre-malignant form of gestational trophoblastic neoplasia.It is the most common form of the disease, and it is benign in nature ${ }^{(1,2,3)}$ There is a wide variation in incidence reported worldwide which has been contributed by genetic, demographic, environmental and hostrelated factors. Protein deficiency, malnutrition and low socio-eco-nomic status also have been associated to this geo-graphic and ethnic distribution, definite environmental factors have not been demonstrated. ${ }^{(4)}$ In Asia, Indonesia has the highest incidence ( 1 in 77 pregnancies and 1 in 57 deliveries).$^{[5,6,7,8]}$ The incidence of GTN varies in different regions from $0.6-1.1$ per 1000 pregnancies in Europe and North America to 2 per 1000 pregnancies in Japan ${ }^{9}$.In Asia, Indonesia has the highest incidence ${ }^{10} 1$ in 77 pregnancies and 1 in 57 deliveries. In India and Middle East the incidence is believed to be 1 in 160 pregnancies ${ }^{11}$

Gestational trophoblastic neoplasms (GTN) are proliferative as well as degenerative disorders of placental elements and include complete or partial hydatidiform mole (90\%), invasive mole (5-8\%) which could also be metastatic, villous or avillous choriocarcinoma (1-2\%), and placental site tumor $(1-2 \%)^{12}$. Gestational trophoblastic disease (GTD) refers to an abnormal trophoblastic proliferation composed of a broad spectrum of lesions ranging from benign, albeit premalignant hydatiform mole (complete and partial), through to the aggressive invasive mole, choriocarcinoma, and placental site trophoblastic tumor (PSTT). Gestational trophoblastic neoplasia (GTN) refers to the aggressive form which has a capability for independent growth and metastases and requires chemotherapy. It includes invasive mole, choriocarcinoma, and PSTT. GTN may arise following evacuation of a molar pregnancy, followed by a normal term or preterm pregnancy, abortion, or ectopic pregnancy. it is also referred to as persistent trophoblastic neoplasia (PTN). GTD may occur as a pregnancy complication in women of any age, it is more common at teenage or advanced maternal age (40-50 years) ${ }^{[13,14]}$ The Royal College of Obstetricians and Gynecologists recommends that suspected complete molar pregnancies should be removed by suction evacuation, while suspected partial molar pregnancy should generally be removed via medical termination .However, hysterectomy is preffered option for good surgical candidates not desirous of future pregnancy and for older women who are likely to develop malignant sequelae. ${ }^{15,16}$

\section{Patients And Methods}

This study was conducted at Regional institute of medical sciences ,IMPHAL Manipur, in the department of obstetrics and gynecology from 1st octo. to 30 th june 2016. The clinical records of molar patients were recorded regarding complete history, mode of presentation, investigations, management and according to follow-up. The information on the age, highest level of educational status, parity, and period of gestational were also included in our study. During the study period, there were 37 cases of Molar pregnancy out of 8104 total deliveries. Investigations included complete blood count, $\beta$-hCG level, blood grouping, X-ray chest and Ultrasonograpghy. The diagnosis of HM was based on a pelvic ultrasound scan, estimation of BhCG and histopathological examination of the specimen. During this period 8104 patients delivered in our hospital. In our study total number of deliveries from $1^{\text {st }}$ October to 30june were 8104 . There were 37 molar 
pregnancies.The incidence was 4.5656 per 1000 deliveries.HCG were raised in both complete and partial mole, the levels were higher in complete moles with comparision to partial moles.Most of the patients in the study groups were christians. Pre- treatment serum $\beta$-hCG level was elevated in almost all patients. The patients were followed up .The information Related to the risk factors, clinical presentations, laboratory results, treatment, follow-up, and the complications of molar pregnancy were included.A total of 37 women with genital tract neoplasia were registered during the study period. Out of these Thirty-four had Hydatidiform mole( 31 complete mole ,3 partial mole)and three were invasive mole.Presenting symptoms were vaginal bleeding, followed by pain in lower abdomen, passage of moles, hyperemesis gravidarum with fever.Out of 37 molar pregnancies, $34(96.96 \%)$ patients managed by suction evacuation, Chemotherapy as single agent (Methotrexate and folinic acid rescue regimen) was given to three patients. Serial measurement of serum $\beta$ hCG level was done during follow up after evacuation.Patient of para one (P1) and above were affected more in comparision with nalliparous. Only 4 patients were above 40 years of age. Women who belongs from poor socioeconomic status,low litracy and remote area belonging were affected more. Amenorrhea, vaginal bleeding and pain in lower abdomen were more common symptoms.Follow- up was done including clinical presentation, USG finding and X-ray chest, and serial $\beta$-hCG measurement, in starting each after 2 weeks for 1-6 weeks or till Serum $\beta$-hCG level became normal, followed by monthly for next 6 months, 3 monthly for further 7-12 months.

\section{Discussion}

The purpose of this study was to explore the incidence and epidemiological correlates of molar pregnancy, the clinical behavior, the complications and management of this disease in our hospital. The details of the records of 37 patients with HM seen and managed at the department of obstetrics and gynecology from 1 st octo. to 30 th june 2016. In our study total number of deliveries from $1^{\text {st }}$ October to 30 june were 8104 and There were 37 molar pregnancies.The incidence was 4.5656 per 1000 deliveries.There is a wide variation in incidence reported worldwide which has been attributed to genetic, environmental, and host-related factors, In our study incidence was 4.5656 per 1000 deliveries. Hydatidiform mole (HM) varies greatly in incidence around the world. It should be noted that patients with uterine size 4 weeks larger than date and the presence of theca lutein cyst of $>6 \mathrm{~cm}$ have a $50 \%$ risk of persistent disease ${ }^{[17]}$. Accurate diagnosis and classification of $\mathrm{H}$. mole is important as the risk of persistent gestational trophoblastic disease including choriocarcinoma is significantly high. The risk of choriocarcinoma in CHM is $10-30 \%$ and in PHM is $0.5 \%-5 \%{ }^{18}$ It is subdivided into complete $\mathrm{HM}$ and partial HM based on the morphologic, cytogenetic and clinicopathologic features. Methotrexate has been found to achieve complete remission in most nonmetastatic and low risk GTN. Etoposide and actinomycin have been found successful as second line of treatment with $97 \%$ response in low risk disease ${ }^{19,20}$. Gestational Trophoblastic Disease produce $\beta$ HCG which therefore acts as a tumor marker. P57kip2 being is most specific and it can be used in difficult cases. Serum $\beta$ HCG levels related with disease,therefor monitoring its levels is used as an accurate biomarker for diagnosis, prognosis and follow up of Gestational Trophoblastic Disease. ${ }^{[21]}$ Following evacuation, in the majority of cases, the residual trophoblast cells are unable to continue to proliferate for long, and the fall in serum hCG level is a very good marker.Chromosomal analysis and flow cytometric studies of ploidy in molar gestations are also used .To differentiate CHM and PHM There are lots of parameters which are used be but clinical findings with histopathology are the main diagnostic tools. In our study highest incidence was found in age group 20-35years., whereas Extremes of reproductive life are important risk factors associated with molar pregnancy.The availability of ultrasound scans and estimation of serum BhCG contributed to the early diagnosis and follow-up of these patients. In our study amenorrhea, vaginal bleeding and pain in lower abdomen were more common symptoms. Low literacy, lack of antenatal care and low socioeconomic conditions remain major contributory factors for late presentation. Hydatidiform mole (HM) varies greatly in incidence around the world and this is due to the fact that many reports lack a clear, and precise definition of the disease, and over-reporting of pregnancies comparision with gestational trophoblastic disease.It should be noted that patients with uterine size 4 weeks larger than date and the presence of theca lutein cyst of $>6 \mathrm{~cm}$ have a $50 \%$ risk of persistent disease ${ }^{[22]}$. However, some studies indicate an increase in the incidence of HM with decreasing maternal age below 20 years, while others report an increased risk in patients over 35 years. ${ }^{23,24,25}$. Berkowitz RS et al13 reported majority of patients diagnosed within 1st trimester often before classical clinical sign and symptoms develop. Late presentation resulted in uterus being larger than dates and appearance of theca lutein cysts in our patients ${ }^{26}$. All patients with evidence of persistent trophoblastic activity in the absence of a new pregnancy should receive chemotherapy.The diagnosis of GTD was based on clinical examination, ultrasonography, $\beta$-hCG level, and on histopathological features. Routine ultrasound examination in 1st trimester of pregnancy would be helpful in early diagnosis of GTD. ${ }^{27}$ The availability of ultrasound scans and estimation of serum BhCG contributed to the early diagnosis and follow-up of these patients.Chemotherapy is now the established method of treatment of choriocarcinoma and hysterectomy and surgical resection of the tumor is rarely required in cases resistant to 
chemotherap $y^{28}$ Given our institutional setting and demographics, we adviced prophylactic chemotherapy for the high-risk group .

\section{Results}

In our study total number of deliveries from $1^{\text {st }}$ October to 30 june were 8104 .There were 37 molar pregnancies. The incidence was 4.5656 per 1000 deliveries.

\begin{tabular}{|l|c|}
\hline Characteristic & Yes \\
\hline Amenorrhea & $91 \%$ \\
\hline Pain abdomen & $93 \%$ \\
\hline Vaginal bleeding & $80 \%$ \\
\hline Hyperemesis gravidarum & $47 \%$ \\
\hline anaemia & $95 \%$ \\
\hline Large for gestation & $61 \%$ \\
\hline Small for gestation & $24 \%$ \\
\hline preclampsia & $4.2 \%$ \\
\hline thyrotoxicosis & $3 \%$ \\
\hline Theca leutin cyst & $3 \%$ \\
\hline hypertension & $20 \%$ \\
\hline dizziness & $6 \%$ \\
\hline fever & $10 \%$ \\
\hline Acute haemrrhage & $25 \%$ \\
\hline shock & $0 \%$ \\
\hline
\end{tabular}

\begin{tabular}{|l|l|}
\hline HYDATIFORM MOLE & $\begin{array}{l}34 \\
\text { (31 COMPLETE, and } \\
\text { PARTIAL -3) }\end{array}$ \\
\hline INVASIVE MOLE & 3 \\
\hline CHORIO CARCINOMA & 0 \\
\hline TOTAL & 37 \\
\hline
\end{tabular}

\begin{tabular}{|l|l|}
\hline \multicolumn{2}{|c|}{ Socioeconomic status } \\
\hline Low & High \\
\hline $86 \%$ & $14 \%$ \\
\hline
\end{tabular}

\begin{tabular}{|l|l|}
\hline \multicolumn{2}{|c|}{ Literacy } \\
\hline Low & High \\
\hline $78 \%$ & $22 \%$ \\
\hline
\end{tabular}

\begin{tabular}{|c|c|}
\hline \multicolumn{2}{|c|}{ Religion } \\
\hline christian & Others \\
\hline $82 \%$ & $18 \%$ \\
\hline
\end{tabular}

\begin{tabular}{|c|c|}
\hline \multicolumn{2}{|c|}{} \\
\hline Remote & Urban \\
\hline $75 \%$ & $25 \%$ \\
\hline
\end{tabular}

We found most of the result from remote area ,low socio economic status and low education level.

\begin{tabular}{|l|l|}
\hline \multicolumn{2}{|c|}{ PARITY } \\
\hline P0 & P1 AND MORE \\
\hline $30 \%$ & $70 \%$ \\
\hline
\end{tabular}

In our study parity one and above were more than $70 \%$. There were thirty percent of nulliparous pregnancy.

\section{Summary}

There is a wide variation in incidence reported worldwide which has been contributed by genetic, environmental, and host-related factors. Laboratory measurement of the serum hCG level and early diagnosis by ultrasound scan can be life saving. In our study total number of deliveries from $1^{\text {st }}$ October to 30 june were 8104 .There were 37 molar pregnancies. The incidence was 4.5656 per 1000 deliveries. We found most of the result from remote area, low socio economic status and low education level women. In our study parity one and above were more than $70 \%$. There were thirty percent of nulliparous pregnancy.For better results they should be followed up properly. 


\section{References}

[1]. Barut A, Arikan I, Harma M, Harma MI, Barut F, Coskan A. Recurrent partial hydatidiform mole. J Pak Med Assoc 2011;61:1016-7.

[2]. Mayun AA. Hydatidiform mole in Gombe: A five year Histopathological review. Niger J Clin Pract2008;11:134-8.

[3]. Savage P. Molar pregnancy. The Obstetrician \& Gynaecologist 2008;10:3-8

[4]. Matsui $\mathrm{H}$ et al. (2008).Changes in the incidence of molar pregnancies. A popu-lation- based study in Chiba Prefecture and Japan between 1974 and 2000. European Society of Human Reproduction and Embryology. Human Reproduc-tion, 18(1), 172-175.

[5]. Smith HO, Qualls CR, Prairie BA, Padilla LA, Rayburn WF, Key CR. Trends in gestational choriocarcinoma: a 27-year perspective. Obstet Gynecol. 2003 Nov;102 (5 Pt 1):978-87.

[6]. Berkowitz RS, Goldstein DP. In: Berck JS. Gestational trophoblastic neoplasm. Philadelphia, Lipincott, Williams and Wilkins, $2002 ; 1353-74$

[7]. Aziz MF, Kampono N, Moigni EM. Epidemiology of gestational trophoblastic neoplasia at the Dr. Cipto Mangukusmo Hospital Jakarta, Indonesia. Adv Exp Med Biol 1984; 176: 165-75.

[8]. Daftary SN, Padubidri VG. Trophoblastic diseases. In: Padubidri VG, Daftary SN (eds). Shaw's Textbook of Gynaecology, 13th edn New Delhi. Elseiver India Ltd. 2004:248-59.

[9]. Berkowitz RS, Goldstein DP. In: Berck JS. Gestational trophoblastic neoplasm. Philadelphia, Lipincott, Williams and Wilkins,2002;1353-74.

[10]. Aziz MF, Kampono N, Moigni EM. Epidemiology of gestational trophoblastic neoplasia at the Dr. Cipto Mangukusmo Hospital Jakarta, Indonesia. Adv Exp Med Biol 1984; 176: 165-75.

[11]. Daftary SN, Padubidri VG. Trophoblastic diseases. In: Padubidri VG, Daftary SN (eds). Shaw's Textbook of Gynaecology, 13th edn New Delhi. Elseiver India Ltd. 2004:248-59.

[12]. Miller FM, Laing FC.Gestational trophoblastic diseasehttp://brighamrad.harvard.edu/cases/bwh/hcache/34/full.html.

[13]. B. J. Wagner, P. J. Woodward, and G. E. Dickey, "From the archives of the AFIP. Gestational trophoblastic disease: radiologicpathologic correlation," Radiographics, vol. 16, no. 1, pp. 131-148, 1996. View at Publisher · View at Google Scholar · View at Scopus

[14]. S. D. Allen, A. K. Lim, M. J. Seckl, D. M. Blunt, and A. W. Mitchell, "Radiology of gestational trophoblastic neoplasia," Clinical Radiology, vol. 61, no. 4, pp. 301-313, 2006

[15]. Aghajanian P. Gestational trophoblastic disease. In: Decherney AH, Nathan L, Goodwin TM, Laufer N, editors. Current Diagnosis Treatment in Obstetrics and Gynaecology 10thed. New York: Mc Craw Hill Medical Publishing Division; 2007. p. 885-95.

[16]. Royal college of Obstetricians and Gynaecologists. The Management of Gestational Trophoblastic Neoplasia. Green Top Guideline No. 38. London: RCOG; 2004.

[17]. 17. D'Couth S et al.(2013). A Retrospective Study of Gestational Trophoblastic Ne- oplasia in a Tertiary Care Centre. J. of Evolution of Medical and Dental Sciences , 2(31), 5813-5819

[18]. Merchant SH, Amin MB , Vishwanatha DS, Malhotra RK, MoehLenkamp , Joste NE . p57kip2 Immunohistochemistry in early molar pregnancies. Emphasis on its complementary role in differential diagnosis of hydropicabortuses. Human Pathol , $36 ; 180$ 86,2005 .

[19]. Homesley HD. Single agent therapy for nonmetastatic and low risk gestational trophoblastic disease. J Reprod Med 1998; 43: 6974.

[20]. Dobson LS, Lorlgan PC, Coleman RE et al. Persistent gestational trophoblastic disease: results of MEA (methotrexate, etoposide and actinomycin) as first line chemotherapy in high risk and EA (ectoposide and actinomycin) as second line chemotherapy for low risk disease. Br J Cancer 2000; 82: 1547-52

[21]. Shih I-M, Mazur M.T, Kurman R.J, Ellenson L.H, Ronnett B.M. Blaustein's Pa- thology of the Female Genital Tract. 6th ed. Springer New York

[22]. D'Couth S et al.(2013). A Retrospective Study of Gestational Trophoblastic Ne- oplasia in a Tertiary Care Centre. J. of Evolution of Medical and Dental Sciences , 2(31), 5813-5819

[23]. La Vacchia CL, Parazzani F, Deanli A, et al. Age of parents of gestational trophoblastic disease. J Nat'1 Cancer Instit. 1984;73:639. [PubMed]

[24]. Nakano R, Sasaki K, Yamato M, Hata H. Trophoblastic disease analysis of 342 patients. Gynecol Obste Invest. 1980;11:237. [PubMed]

[25]. Matsuura J, Chiu D, Jacobs PA, Szulman AE. Complete hydatidiform mole in Hawaii. An epidemiological study. Genet Epidemiol. 1984;1:171. [PubMed]

[26]. Berkowitz RS, Goldstein DP. Molar pregnancy. N Engl J Med 2009;360(16):1639-45.

[27]. Rauf B, Hassan L, Ahmed S. Management of Gestational Trophoblastic Tumor: A Five-year Clinical Experience. J Coll Physicians Surg Pak 2004;14(9):540-4. 15. Jain KA, Gestational Trophoblastic Disease: Pictorial review. Ultrasound Q 2005;21:245-53. 16. Zhou Q, Lei XY, Xie Q, Cardoza JD. Sonographic and Doppler Imaging in the Diagnosis and Treatment of Gestational Trophoblastic Disease. A 12-Year Experience. J Ultrasound Med 2005;24;15-24.

[28]. Berkowits RS, Goldstein DP. The management of molar pregnancy and gestational trophoblastic tumors. In: Knapp RC, Berkowitz RS, editors. Gynecologic Oncology. 2nd ed. New York: McGraw-Hill; 1993. pp. 328-38. 